\title{
PENGARUH DESAIN DAN KINERJA ELEVATOR TERHADAP MOBILITAS PENGGUNA DI UNIVERSITAS MATANA
}

Juan Nata ${ }^{1}$, Irene Meylinda ${ }^{2}$

Program Studi Arsitektur, FSTEM, Universitas Matana ${ }^{1,2}$

\begin{abstract}
Abstrak
Elevator sebagai transportasi vertikal pada bangunan bertingkat banyak menjadi bagian dari sirkulasi dalam bangunan yang cukup penting. Sebagai alat transportasi vertikal, elevator membantu perpindahan tiap lantai pengguna bangunan tersebut, dan secara langsung memengaruhi pola sirkulasi bangunan tersebut. Oleh karena itu ketersediaan alat transportasi vertikal yang baik sangat berpengaruh terhadap mobilitas pengguna di dalam bangunan tersebut. Aktivitas dan perpindahan pengguna sangat dipengaruhi oleh pola sirkulasi dan desain bagunan (peruntukan atau tipologi bangunan tersebut). Untuk mengetahui pengaruh desain dan kinerja elevator terhadap mobilitas pengguna di Universitas Matana, dilakukan penelitian kuantitatif dengan mengadakan kuesioner terhadap 50 responden di Universitas Matana, lalu data tersebut diolah dengan software SPSS untuk diuji validitas dan reliabilitasnya dan diuji hipotesisnya yang meliputi uji korelasi, koefisien determinasi, uji signifikansi, dan persamaan regresi. Dari penilitan didapatkan hasil bahwa memang ada hubungan yang kuat dan signifikan dengan rhitung $=0,608$ dan thitung $=5.302$ antara desain dan kinerja elevator dengan mobilitas pengguna di Universitas Matana, meskipun pengaruh antra variabel tersebut hanya sebesar $36,96 \%$.
\end{abstract}

Kata Kunci : Kinerja Elevator, Mobilitas, Pola Sirkulasi, Pola Aktivitas.

\begin{abstract}
Elevators as vertical transportation in multi-storey buildings are a significant part of the circulation in buildings. As a vertical means of transportation, elevators help move each floor of the building user, and directly affect the circulation pattern of the building. Therefore, the availability of good vertical transportation is very influential on the mobility of users in the building. User activities and movements are strongly influenced by circulation patterns and building designs (designation or typology of the building). To find out the effect of design and elevator performance on user mobility at Matana University, quantitative research was conducted by holding questionnaires on 50 respondents at Matana University, then the data was processed with SPSS software to be tested for validity and reliability and tested hypotheses which included correlation test, determination coefficient, significance test, and regression equation. From the research, it was found that there was indeed a strong and significant relationship with rcount $=0.608$ and tcount $=$ 5.302 between the design and performance of elevators with user mobility at Matana University, although the influence between these variables was only $36.96 \%$.
\end{abstract}


Keywords : Elevator Performance, Mobility, Circulation Patterns, Activity Patterns.

\section{Pendahuluan}

Peran elevator sebagai alat transportasi vertikal sangatlah penting dalam bangunan berlantai banyak (mid-rise dan high-rise). Elevator adalah alat transportasi yang digunakan untuk memindahkan orang-orang secara vertikal antar lantai-lantai pada suatu bangunan (Nashrulhaq, dkk, 2014). Sebagai alat transportasi vertikal, elevator membantu perpindahan tiap lantai pengguna bangunan tersebut, dan secara langsung memengaruhi pola sirkulasi bangunan tersebut.

Dalam teknis pelaksanaanya, desain dan kinerja elevator dipengaruhi beberapa faktor seperti:

1. Lama perjalanan (waktu tempuh)

2. Daya angkut (kapasitas)

3. Waktu tunggu - antrean

4. Tata letak dan konfigurasi

Hubungan sirkulasi dalam bangunan selanjutnya berkaitan dengan mobilitas pengguna di dalam bangunan tersebut. Mobilitas menurut KBBI adalah gerakan; perpindahan, kesiapsiagaan untuk bergerak (KBBI Daring, 2018). Kata mobilitas dalam konteks ini mengacu kepada aktivitas dan perpindahan pengguna di Universitas Matana.

Dalam pelaksanaannya, mobilitas berhubungan dengan beberapa faktor seperti:

1. Pengguna: Pelaku yang dimaksud adalah semua individu atau personel yang terlibat langsung maupun tidak langsung dalam lingkup kawasan, dalam hal ini Kampus Universitas Matana (Akhsan, dkk, 2015).

2. Sirkulasi: Pergerakan yang menghubungkan ruang-ruang dalam suatu bangunan atau suatu deretan ruang dalam dan ruang luar secara bersama (Pratama, dkk, 2018).

3. Aktivitas: Segala bentuk aktivitas dan interaksi antara pengguna dengan pengguna lain maupun pengguna dengan lingkungan kawasannya, dalam hal ini Kampus Universitas Matana.

\section{Metode Penelitian}

Penelitian ini dilakukan untuk mengetahui pengaruh desain dan kinerja elevator terhadap mobilitas pengguna di Universitas Matana. Untuk mengetahui ada atau tidaknya pengaruh antara kedua variabel tersebut, dilakukan pengumpulan data dengan metode kuantitatif dengan cara mengadakan kuesioner terhadap 50 responden di Universitas Matana (pengguna fasilitas kampus) dari Mahasiswa, Dosen dan Staff. Kuesioner yang diberikan menggunakan Google Form dengan indikator variabel $[\mathrm{X}]$ : desain dan kinerja elevator dan variabel [Y]: mobilitas pengguna di Universitas Matana. 
Data lalu diproses dengan software SPSS untuk menguji validitas dan reliabilitas data dan menguji hipotesis yang meliputi uji korelasi, koefisien determinasi, uji signifikansi, dan persamaan regresi (Sugiono, 2013). Dalam mengetahui pengaruh, hubungan perlu diketahui dulu (Damayanthi dan Khamdevi, 2015).

\begin{tabular}{|c|c|c|c|}
\hline \multicolumn{2}{|c|}{ Variabel $[\mathrm{X}]$ - Independen } & & \\
\hline Indikator & Sub Indikator & & \\
\hline \multirow{2}{*}{ Daya angkut } & kapasitas elevator & & \\
\hline & kenyamanan & & \\
\hline \multirow{2}{*}{ Waktu tempuh } & waktu tempuh & & \\
\hline & luasan lobby elevator & & \\
\hline \multirow{5}{*}{$\begin{array}{l}\text { Tata letak \& } \\
\text { desain }\end{array}$} & lokasi & \multicolumn{2}{|c|}{ Variabel [Y] - Dependen } \\
\hline & konfigurasi desain & Indikator & Sub Indikator \\
\hline & konfigurasi tombol & \multirow{2}{*}{ Pengguna } & aktivitas pengguna \\
\hline & dalam elevator & & aktivitas pengguna \\
\hline & $\begin{array}{l}\text { kenyamanan lobby } \\
\text { elevator }\end{array}$ & \multirow{3}{*}{ Sirkulasi } & $\begin{array}{l}\text { tata letak dan pola } \\
\text { sirkulasi }\end{array}$ \\
\hline \multirow{2}{*}{ Mekanis } & mekanis elevator & & \multirow{2}{*}{$\begin{array}{l}\text { tata letak dan pola } \\
\text { sirkulasi }\end{array}$} \\
\hline & pintu elevator & & \\
\hline Mekanis & tombol elevator & \multirow{5}{*}{ Aktivitas } & \multirow{2}{*}{$\begin{array}{l}\text { Sirkulasi dan } \\
\text { mobilitas }\end{array}$} \\
\hline \multirow{4}{*}{ Pengguna } & preferensi pengguna & & \\
\hline & preferensi pengguna & & \multirow{2}{*}{$\begin{array}{l}\text { konfigurasi desain } \\
\text { dan mobilitas }\end{array}$} \\
\hline & \multirow{2}{*}{$\begin{array}{l}\text { preferensi pengguna } \\
\text { dan antrean }\end{array}$} & & \\
\hline & & & antrean dan mobilitas \\
\hline
\end{tabular}

\section{Hasil dan Pembahasan}

Pengambilan sampel dilakukan di Universitas Matana, dengan target responden pengguna bangunan Kampus Universitas Matana. Pengguna yang dimaksud adalah semua individu atau personel yang terlibat langsung maupun tidak langsung dalam aktivitas di Kampus (dalam hal ini Universitas Matana).

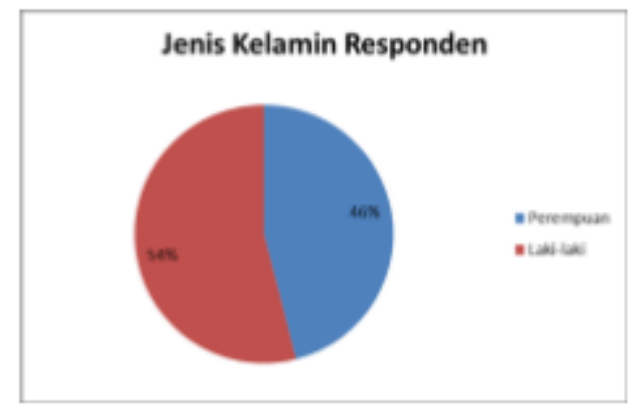

Grafik 1. Jenis kelamin responden

Grafik 1. menunjukan bahwa responden yang mengisi kuesioner berjenis kelamin lakilaki dengan jumlah 27 orang sedangkan untuk perempuan 23 orang. 


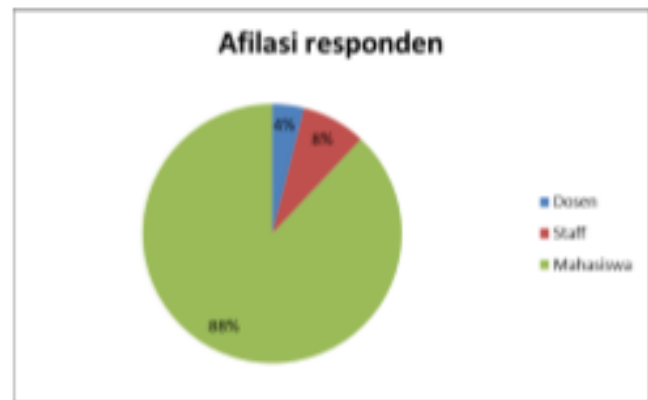

Grafik 2. Afilasi responden

Pada grafik 2. menunjukan afilasi responden di Universitas Matana. Responden terbanyak datang dari Mahasiswa dengan jumlah 44 responden, lalu dari staff Universitas Matana dengan jumlah 4 responden, dan dari Dosen Universitas Matana dengan jumlah 2 responden.

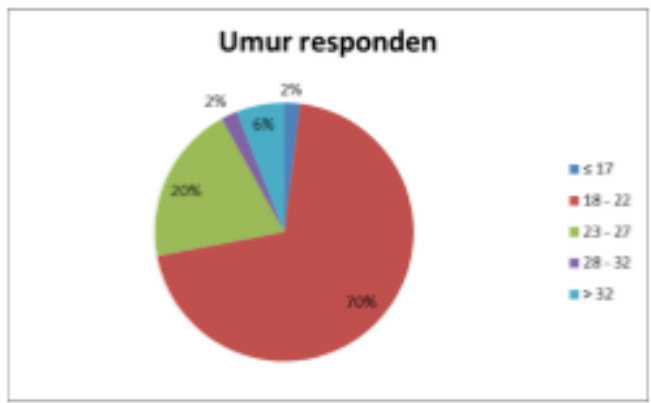

Grafik 3. Rentang umur responden

Lalu Grafik 3. menunjukan rentangan umur responden. Dengan responden terbanyak berada di rentang umur 18 sampai 22 tahun dengan jumlah 35 responden. Sedangkan responden paling sedikit berada di rentang umur kurang dari 17 tahun dan 28 sampai 32 tahun masing-masing berjumlah 1 responden.

Dari hasil kuesioner, didapat hasil sebagai berikut. Pada pernyataan 1 mengenai kapasitas elevator, sebanyak 22 responden setuju bahwa banyaknya penumpang yang dapat ditampung sudah mencukupi. Lalu pada pernyataan 2, sebanyak 17 responden setuju elevator cukup nyaman dalam kapasitas maksimal, diikuti dengan respon raguragu dari 14 responden.

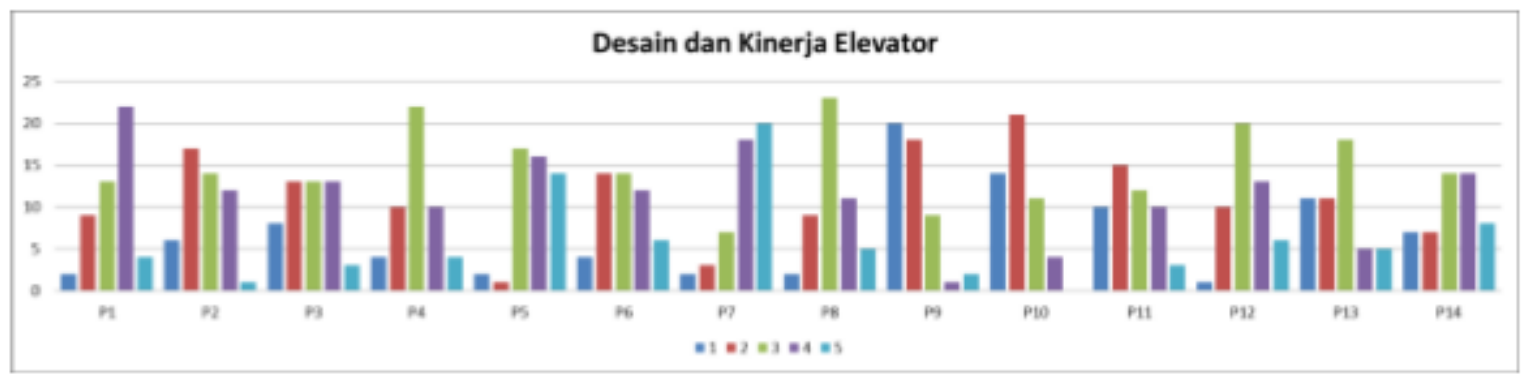

Grafik 4. Hasil kuesioner mengenai desain dan kinerja elevator [X].

Pada pernyataan 3 mengenai waktu tempuh, respon setuju, ragu-ragu, dan tidak setuju memiliki jumlah yang sama yaitu 13 responden. Pada pernyataan 4 mengenai waktu tunggu dan hubungannya kepada desain lobby elevator, respon terbanyak sebanyak 22 responden menyatakan ragu-ragu bahwa lobby elevator sudah cukup luas untuk menunggu elevator. 
Pada pernyataan 5 mengenai tata letak dan desain elevator, sebanyak 17 responden menyatakan ragu-ragu mengenai lokasi elevator yang mudah dicapai, diikuti dengan respon setuju dari 16 responden. Lalu pada pernyataan 6, sebanyak 14 respon menyatakan ragu-ragu dan tidak setuju mengenai Konfigurasi elevator sudah baik ( 2 elevator penumpang dan 2 elevator servis). Pada pernyataan 7 , sebanyak 20 responden menyatakan setuju mengenai konfigurasi tombol dalam elevator sudah tepat dan dapat dimengerti dengan mudah. Pada pernyataan 8, sebanyak 23 responden ragu-ragu mengenai kenyaman lobby elevator untuk menunggu elevator.

Pada pernyataan 9 mengenai mekanis elevator, sebanyak 20 responden menyatakan sangat tidak setuju bahwa seluruh elevator yang tersedia telah berfungsi dengan baik, diikuti dengan 18 respon tidak setuju. Pada pernyataan 10, sebanyak 21 responden tidak setuju mengenai pintu elevator dapat berfungsi dengan baik. Lalu pada pernyataan 11, sebanyak 15 responden menyatakan tidak setuju mengenai semua tombol dalam elevator berfungsi dengan baik dengan indikator yang tepat.

Pada pernyataan 12 mengenai preferensi pengguna, sebanyak 20 responden menyatakan raguragu bahwa pengguna lebih memilih untuk menggunakan elevator penumpang daripada elevator servis. Pada penyataan 13 , sebanyak 18 responden menyatakan raguragu bahwa Pengguna lebih memilih menunggu elevator penumpang meskipun elevator servis telah tersedia terlebih dahulu. Lalu padaada pernyataan 14, sebanyak 14 responden menyatakan ragu-ragu dan setuju bahwa pengguna lebih memilih menggunakan tangga darurat (meskipun terbatas) dibanding menunggu/mengantre untuk elevator.

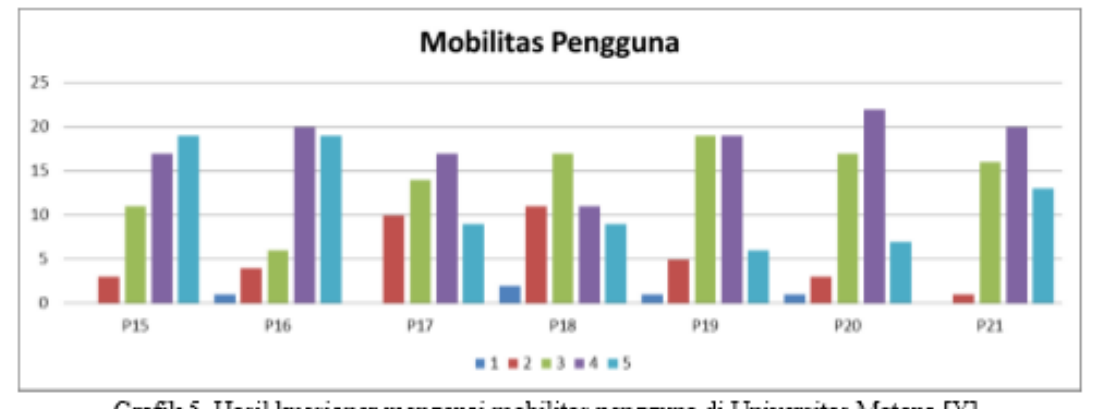

Grafik 5. Hasil kuesioner mengenai mobilitas pengguna di Universitas Matana [Y]

Pada pertanyaan 15, sebanyak 19 responden menyatakan sangat setuju Pengguna biasanya berpindah lebih dari 2 lantai setiap harinya. Lalu pada pernyataan 16, sebanyak 20 responden menyatakan setuju bahwa pengguna beraktivitas di lebih dari 1 lantai setiap harinya. Dengan kata lain, responden memiliki mobilitas tinggi di Universitas Matana, terutama dalam aktivitas perpindahan level (vertikal).

Pada pernyataan 17, sebanyak 17 responden menyatakan setuju bahwa sirkulasi tiap lantai (tipikal) dan lobby di Universitas Matana sudah baik dan mudah dimengerti, diikuti dengan 14 responden menyatakan ragu-ragu. Lalu pada pernyataan 18 , sebanyak 17 responden menyatakan ragu-ragu terhadap Peletakan ruang - ruang di tiap lantai (tipikal) dan lobby di Universitas Matana sudah sesuai dengan aktivitas Kampus.

Pada pernyataan 19, respon setuju dan ragu-ragu mengenai pola sirkulasi di Universitas Matana memengaruhi pergerakan pengguna dalam berpindah level/lantai secara signifikan, memiliki jumlah yang sama yaitu 19 responden. Pada pernyataan 20, sebanyak 22 responden menyatakan setuju bahwa Tata letak ruang-ruang di Universitas matana memengaruhi pergerakan pengguna 36 | Volume II Nomor 21 Februari 2019 
dalam berpindah level/lantai secara signifikan. Lalu pada pernyataan 21, sebanyak 20 responden menyatakan setuju mengenai Kepadatan manusia di Universitas Matana memengaruhi pergerakan pengguna dalam berpindah level/lantai secara signifikan. Dengan kata lain, mobilitas di Universitas Matana sangat dipengaruhi oleh desain dan keadaan dan desain Kampus saat ini. Hal ini bisa berhubungan dengan bangunan Kampus yang pada awalnya diperuntukan sebagai Apartemen.

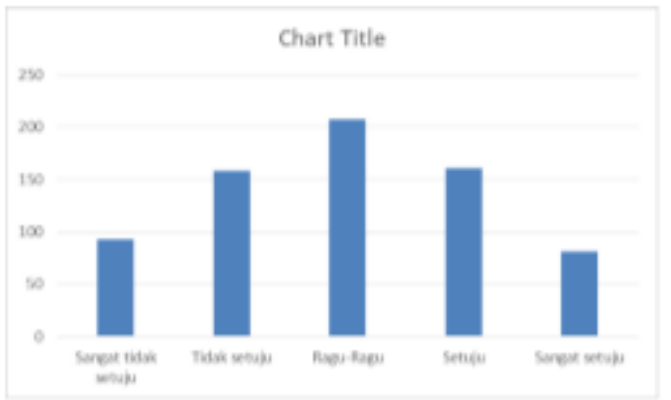

Grafik 6. Tanggapan responden terhadap desain dan kinerja elevator [X]

Dari grafik 6. dapat dilihat bahwa tanggapan responden terhadap desain dan kinerja elevator di Universitas Matana cukup atau ragu-ragu. Dari sini dapat terlihat bahwa desain dan kinerja elevator di Universitas Matana hanya sekadar cukup untuk memenuhi standard atau keadaan yang ada sekarang ini.

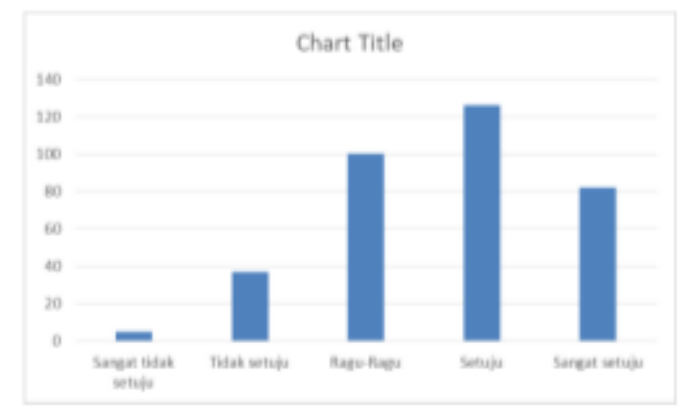

Grafik 7. Tanggapan responden terhadap mobilitas pengguna [Y]

Dari grafik 7. dapat dilihat bahwa para responden setuju dengan mobilitas di Universitas Matana sangat dipengaruhi oleh desain bangunan Kampus. Dari aktivitas pengguna hingga desain bangunan secara keseluruhan sangat memengaruhi mobilitas pengguna (responden) terutama dalam perpindahan level (sirkulasi vertikal). Dari sini dapat terlihat bahwa mobilitas yang dipengaruhi oleh aktivitas dan mobilitas yang dipengaruhi oleh desain bangunan sama kuatnya dari pernyataan positif tentang keduanya.

\section{Uji Validitas}

Uji validitas yang dilakukan menggunakan korelasi Pearson dalam software SPSS. Uji validitas ini bertujuan untung mengetahui apakah setiap pernyataan yang diberikan dalam kuesioner sudah valid untuk mengukur variabel-variabel yang diteliti. Dari uji validitas didapatkan hasil sebagai berikut. 


\begin{tabular}{|l|r|r|l|}
\hline Pernyataan & R hitung & R tabel & Ket. \\
\hline P1 & 0,606 & 0,238 & valid \\
\hline P2 & 0,741 & 0,238 & valid \\
\hline P3 & 0,578 & 0,238 & valid \\
\hline P4 & 0,581 & 0,238 & valid \\
\hline P5 & 0,4 & 0,238 & valid \\
\hline P6 & 0,328 & 0,238 & valid \\
\hline P7 & 0,342 & 0,238 & valid \\
\hline P8 & 0,466 & 0,238 & valid \\
\hline P9 & 0,6 & 0,238 & valid \\
\hline P10 & 0,611 & 0,238 & valid \\
\hline P11 & 0,754 & 0,238 & valid \\
\hline P12 & 0,53 & 0,238 & valid \\
\hline P13 & 0,487 & 0,238 & valid \\
\hline P14 & 0,12 & 0,238 & not valid \\
\hline
\end{tabular}

Tabe1 1. Hasil uji validitas pernyataan-pernyataan variable [X]

\begin{tabular}{|l|r|r|l|}
\hline Pernyataan & R hitung & R tabel & Ket. \\
\hline P15 & 0,706 & 0,238 & valid \\
\hline P16 & 0,691 & 0,238 & valid \\
\hline P17 & 0,745 & 0,238 & valid \\
\hline P18 & 0,78 & 0,238 & valid \\
\hline P19 & 0,743 & 0,238 & valid \\
\hline P20 & 0,714 & 0,238 & valid \\
\hline P21 & 0,388 & 0,238 & valid \\
\hline
\end{tabular}

Tabe1 2. Hasil uji validitas pernyataan-pernyataan variable [Y]

Dari tabel di atas, dapat dilihat bahwa terdapat 1 pernyataan pada variabel $[\mathrm{X}]$ yang tidak valid pada pernyataan nomor 14 yaitu mengenai 'Pengguna lebih memilih menggunakan tangga darurat (meskipun terbatas) dibanding menunggu/mengantre untuk elevator.'. Sedangkan pernyataan lainnya valid dengan $\mathrm{R}$ hitung lebih besar dari R tabel. Maka, pernyataan nomor 14 dan hasilnya tidak diikut sertakan dalam tahap selanjutnya dari penelitian ini.

\section{Uji Reliabilitas}

Pengukuran reliabilitas yang dilakukan menggunakan rumus Cronbach Alpha dalam software SPSS. Uji reliabilitas ini menyertakan seluruh komponen pernyataan pada setiap variable yang 'valid' dan mengabaikan komponen pernyataan yang 'tidak valid'. Dari uji reliabilitas didapatkan hasil sebagai berikut.

\section{[X]}

\section{Reliability Statistics}

\section{Cronbach's}

\begin{tabular}{r|r} 
Alpha & $\mathrm{N}$ of Items \\
\hline .803 & 13 \\
\hline
\end{tabular}


[Y]

\section{Reliability Statistics}

\section{Cronbach's}

\begin{tabular}{r|r} 
Alpha & N of Items \\
\hline .812 & 7 \\
\hline
\end{tabular}

Tabe1 4. Hasil uji relibilitas variabel [Y]

Dalam Sujarweni (2012) uji reliabilitas Cronbach Alpha untuk 20 komponen varibel, dan dapat dikatan reliable jika nilai Alphanya lebih besar dari nilai signifikansi tersebut. Lalu, dari tabel di atas didapat bahwa setiap komponen dalam variabel $X$ maupun variabel $Y$ telah riliabel dan dapat dilanjutkan ke tahap penelitian selanjutnya.

\section{Uji Korelasi}

Uji korelasi yang dilakukan menggunakan software SPSS dengan metode koefisien korelasi Product Moment Pearson untuk mengetahui tingkat hubungan antara variable yang diteliti, dimana:

$r_{\text {hitung }}>r_{\text {tabel; }}$ Ho ditolak, Ha diterima $r_{\text {hitung }}<r_{\text {tabel; }}$ Ho diterima, Ha ditolak.

dengan, $H o=$ tidak ada hubungan $\mathrm{Ha}=$ ada hubungan .

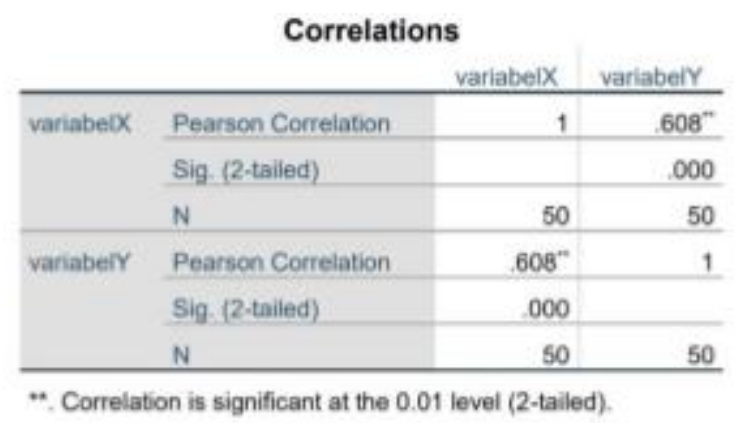

Tabe1 5. Hasil uji korelasi antar variabel.

Dari hasil perhitungan didapat koefisen korelasi ( $r_{\text {hitung }}$ ) sebesar 0,608 yang mana masuk dalam skala kuat (Sujarweni dan Endrayanto, 2012). Sedangkan untuk $r_{\text {tabel }}$ dari 50 responden dengan signifikansi two-tailed ( $r$ pada $\alpha$ 5\%) adalah 0,238 (Sujarweni dan Endrayanto, 2012). Dengan

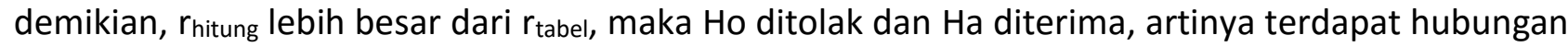
antara variabel $[\mathrm{X}]$ dengan variabel $[\mathrm{Y}]$. Lalu, dari hasil perhitungan tersebut tersebut dapat diketahui bahwa terdapat hubungan yang kuat antara kinerja dan desain elevator dengan mobilitas pengguna di Universitas Matana (Sugiono, 2013). 


\begin{tabular}{|c|c|} 
Interval Koefisien & Tingkat Hubungan \\
\hline $0,00-0,199$ & Sangat rendah \\
\hline $0,20-0,399$ & Rendah \\
\hline $0,40-0,599$ & Sedang \\
\hline $0,60-0,799$ & Kuat \\
\hline $0,80-1,000$ & Sangat kuat \\
\hline
\end{tabular}

Tabel 6.Pedoman untuk memberikan interpretasi koefisien korelasi.

\section{Koefisien Determinasi}

Untuk mengetahui seberapa besar variabel $[\mathrm{X}]$ memengaruhi variable $[\mathrm{Y}]$ maka dicari koefisien determinasinya (koefisien penentu) dengan rumus:

$K d=r^{2} \times 100 \%$

Maka Kd $=(0,608)^{2} \times 100 \% \mathrm{Kd}=36,96 \%$

Dari hasil perhitungan koefisen determinasi didapat bahawa pengaruh variabel $[X]$ : desain dan kinerja elevator terhadap variabel $[\mathrm{Y}]$ : mobilitas pengguna di Universitas Matana hanya sebesar $36,96 \%$ yang mana sisanya $63,04 \%$ dapat dipengaruhi oleh faktor lain seperti pola aktivitas, desain bangunan, maupun kepadatan pengguna itu sendiri.

\section{Uji Signifikansi}

Untuk mengetahui signifikansi korelasi antara variable, dilakukan uji signifikansi menggunakan software SPSS dengan metode regresi linear sederhana. Dimana:

$t_{\text {hitung }}>t_{\text {tabel; }}$ Ho ditolak, Ha diterima $t_{\text {hitung }}<t_{\text {tabel; }}$ Ho diterima, Ha ditolak

dengan, $\mathrm{Ho}=$ tidak signifikan $\mathrm{Ha}=$ signifikan

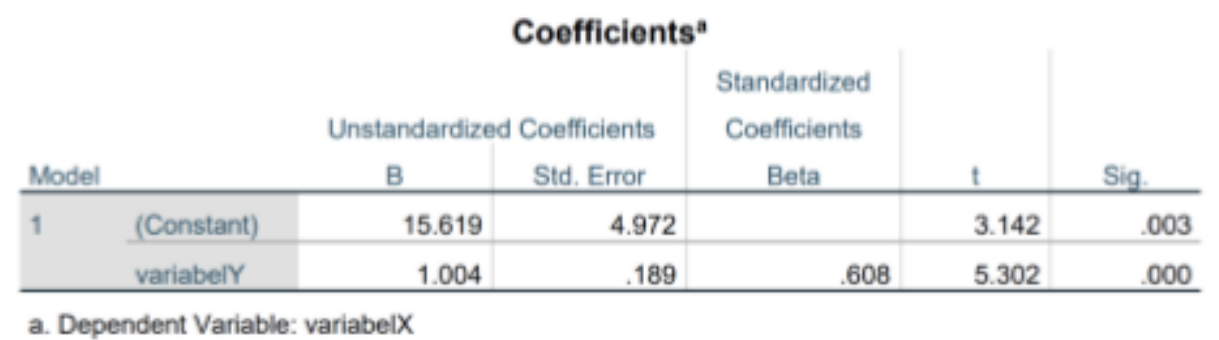

Tabe1 7. Hasil uji Signifikansi

Dari perhitungantersebut didapat $t_{\text {hitung }}$ sebesar 5.302. Selanjutnya dicari $t_{\text {tabel }}$ dengan tingkat signifikansi two-tailed $5 \%$ atau sebesar 1,677 untuk 50 responden (Sujarweni dan Endrayanto, 2012). Dengan demikian, $t_{\text {hitung }}$ lebih besar dari $t_{\text {tabel, }}$ maka Ho ditolak dan Ha diterima, artinya terdapat hubungan signifikan antara variabel $[\mathrm{X}]$ dengan variabel $[\mathrm{Y}]$. 


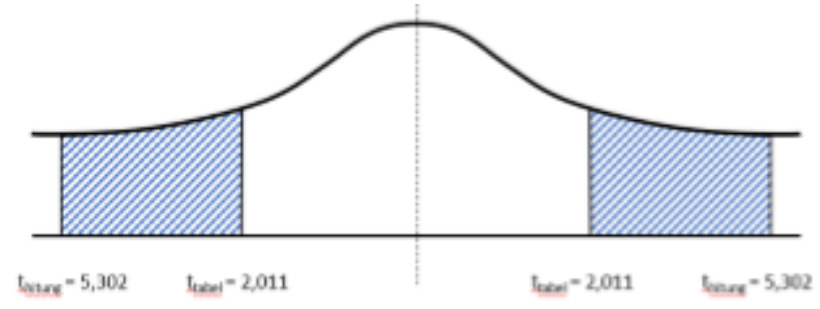

Grafik 8. Kurva Signifikasi Korelasi.

\section{Persamaan Regresi}

Selanjutnya untuk melihat seberapa signifikan hubungan antara desain dan kinerja elevator dengan mobilitas pengguan di Universitas Matana, maka dilakukan perhitungan regresi linear sederhana dengan persamaan:

$y=a+b x$

dimana, $\mathrm{a}=$ konstanta dependent $\mathrm{b}=$ konstanta independent $\mathrm{x}=$ variabel dependent

berdasarkan perhitungan uji signifikansi didapat nilai $a=15,619$ dan nilai $b=1,004$. Maka bentuk pengaruh antara variabel $[\mathrm{X}]$ : desain dan kinerja elevator terhadap variabel $[\mathrm{Y}]$ : mobilitas pengguna di Universitas Matana dapat dinyatakan dengan persamaan regresi:

$y=15,619+1,004 x$

Dari persamaan tersebut, jika nilai variabel $[\mathrm{X}]$ bertambah 10 , maka nilai variabel $[\mathrm{Y}]$ menjadi:

$y=15,619+1,004(10)$

$y=25,659$

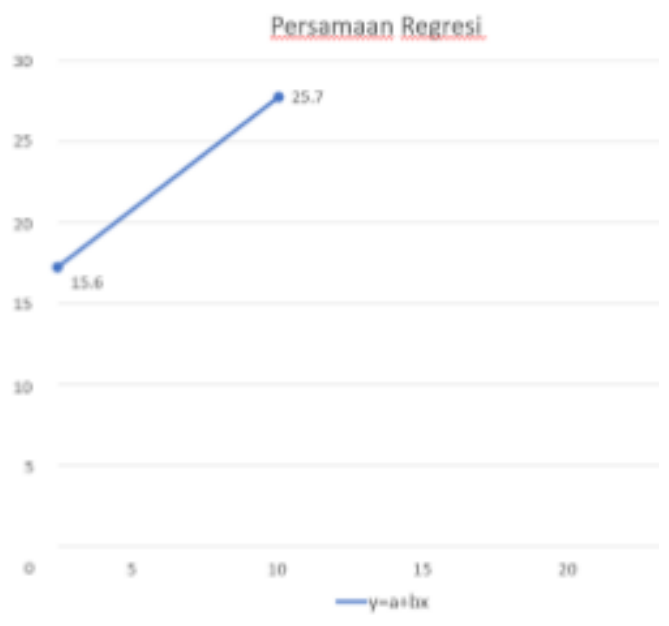

Grafik 9. Grafik Persamaan Regresi. 


\section{Kesimpulan}

Dari hasil uji kuisioner diketahui koefisien korelasi ( $r_{\text {hitung }}$ ) dari penelitian ini ialah sebesar 0,608 termasuk dalam skala kuat, berarti dapat ditemukan hubungan positif antara desain dan kinerja elevator terhadap mobilitas pengguna di Universitas Matana. Pada rtabel terlihat bahwa untuk $\mathrm{n}=$ 50 dengan taraf kesalahan sebesar 5\% maka harga rtabel =0,238. Dari hasil perhitungan didapat koefisen korelasi (rhitung) $=0,608$. Dengan demikian, rhitung lebih besar dari $r_{\text {tabel, maka Ho }}$ ditolak dan Ha diterima, artinya terdapat hubungan positif antara variabel [X] dengan variabel [Y]. Kemudian untuk mengetahui koefisen determinasi dari kedua variabel ditemukan bahwa pengaruh variabel $[\mathrm{X}]$ : desain dan kinerja elevator terhadap variabel $[\mathrm{Y}]$ : mobilitas pengguna di Universitas Matana hanya sebesar 36,96\% yang mana sisanya 63,04\% dapat dipengaruhi oleh faktor lain seperti pola aktivitas, desain bangunan, maupun kepadatan pengguna itu sendiri. Hasil perhitungan thitung sebesar 5,302. Selanjutnya dicari tabel dengan tingkat signifikansi two-tailed $5 \%$ atau sebesar 2,011 untuk 50 responden. Dengan demikian, thitung lebih besar dari tabel, maka Ho ditolak dan Ha diterima, artinya terdapat hubungan yang signifikan antara variabel $[X]$ dengan variabel [Y]. Dari rekapitulasi data, maka didapat kesimpulan, bahwa:

1. Dapat dikatakan bahwa mahasiswa merasa ragu - ragu terhadap keadaan desain dan kinerja elevator di Universitas Matana saat ini.

2. Pola sirkulasi pengguna di Universitas Matana, sudah cukup baik dan mudah dipahami oleh para penggunanya. Hal ini memengaruhi mobilitas pengguna dalam perpindahan vertikal maupun horizontal di Universitas Matana.

Maka perlu direkomendasikan untuk memperhatikan beberapa hal indikator desain dan kinerja elevator dalam pengaruhnya terhadap mobilitas pengguna, yakni: kapasitas, waktu tempuh, tata letak, dan mekanis.

\section{Daftar Pustaka}

Akhsan, M. Nur. Dkk. (2015). “Perancangan Kawasan Gedung Kampus Universitas Pandanaran (Dengan Pendekatan Desain Arsitektur Modern)". Vol. 1 No.1. Semarang. Universitas Pandanaran. Damayanthi, V., Khamdevi, M. (2015). "Pengaruh Setting Peron Terhadap Adaptabilitas Pengguna Krl Studi Kasus: Stasiun Kereta Api Kebayoran Pada Jam Sibuk". Jurnal NalArs Vol 14 No 1. Jakarta: Universitas Mercubuana.

Nashrulhaq, Mochamad Iqbal. Dkk. (2014). “Model Simulasi Sistem Antrean Elevator”. Vol. 2 No.1. Bandung: Institut Teknologi Nasional.

Pratama, Galeh Nur Indriatno Putra. Dkk. (2018). “Aksesibilitas Tata Letak Elevator Penumpang Gedung Kantor Pusat Layanan Terpadu (Kplt) Fakultas Teknik UNY". Vol. 4 No.1. Yogyakarta. Universitas Negeri Yogyakarta.

Sugiono, (2013). "Metode Penelitian Kuantitatif, Kualitatif, dan R\&D”. Bandung: Alfabeta.

Surjawerni, V. Wiratna. Dkk. (2012). "Statistika untuk Penelitian". Halaman 196-201. Yogyakarta: Graha Ilmu.

Trihendradi, C. (2013). "Langkah Praktis Menguasai Statistik untuk Ilmu Sosial Kesehatan Konsep \& Penerapannya Menggunakan SPSS". Yogyakarta: Andi Offset. 